\title{
INDIVIDUAL REFUSALS TO DEAL: WHEN DOES SINGLE-FIRM CONDUCT BECOME VERTICAL RESTRAINT?
}

\author{
CARL H. FULDA*
}

Forty-six years ago the Supreme Court of the United States, in United States $v$. Colgate \& Co., unanimously observed,

The purpose of the Sherman Act is ... to preserve the right of freedom to trade. In the absence of any purpose to create or maintain a monopoly, the act does not restrict the long recognized right of trader or manufacturer engaged in an cntirely private business, freely to exercise his own independent discretion as to parties with whom he will deal; and, of course, he may announce in advance the circumstances under which he will refuse to sell. ${ }^{2}$

This statement was offered in justification of the Court's affirmance of a judgment setting aside an indictment that had charged Colgate with an unlawful combination to establish the resale prices of its dealers. The Court emphasized that the indictment did "not charge Colgate \& Co. with selling its products to dealers under agreements which obligated the latter not to resell except at prices fixed by the company."3

No useful purpose would be served by boring the reader with a discussion of the subsequent cases in the Supreme Court ${ }^{4}$ except the most recent one, United States v. Parke, Davis \& Co. ${ }^{5}$ There a majority of six justices reversed the district court, which had dismissed the Government's complaint charging that the company had combined and conspired with its wholesalers and retailers to maintain the resale prices of its products. The district judge held that "the actions of defendant were properly unilateral and sanctioned by law under the doctrine laid down in" the Colgate case; ${ }^{6} \mathrm{Mr}$. Justice Brennan, writing for the majority, explained that the visits

- J.U.D. 1931, Freiburg, Germany; LL.B. 1938, Yale University. Hugh Lamar Stone Professor of Law, University of Texas.

I am indebted to John Stayton, a third year student in the University of Texas School of Law, for assistance in the collection of cases.

1250 U.S. 300 (1919).

2Id. at 307. The citation for the Sherman Act is 26 Stat. 209 (I890), as amended, I5 U.S.C. $\$ 5 \mathrm{I}-7$ (1964).

3250 U.S. at 307. (Emphasis added.)

"The story has been superbly told in Barber, Refusals 10 Deal Under the Federal Antitrust Laws, I03 U. Pa. L. Rev. 847 (1955). See also ATt'y Gen. Nat'i Comm. Antrtrust Rep. 132-37 (1955). The principal cases are Times-Picayune Publishing Co. v. United States, 345 U.S. 594, 625 (1953) ["Refusals to sell, without more, do not violate the law"; in this connection the Court cited Comment, Refusals to Sell and Public Control of Competition, 58 YALE L.J. I12X (1949)]; United States v. Bausch \& Lomb Optical Co., 32I U.S. 707 (I944); FTC v. Beech-Nut Packing Co., 257 U.S. 44I (1922); United States v. A. Schrader's Son, Inc., 252 U.S. 85 (1920).

${ }_{3} 62$ U.S. 29 (r960).

I64 F. Supp. 827,829 (D.D.C. 1958). 
of company officials to wholesalers and retailers, their discussions about the company's price policies, and the furnishing of names of noncomplying retailers to wholesalers, coupled with the seeking of assurances to deny Parke, Davis products to such retailers, entwined "the wholesalers and retailers in a program to promote general compliance with ... [the company's] price maintenance policy" and "went beyond mere customer selection," thus creating "combinations or conspiracies to enforce resale price maintenance in violation of sections $I$ and 3 of the Sherman Act."7 The manufacturer may impose his will as to resale prices only by "a mere refusal to sell."

Mr. Justice Harlan's dissent referred to the Government's explicit statement that Colgate should not be overruled and to the Court's profession that it had not done so. Nevertheless, he viewed the decision as sending "to its demise the Colgate doctrine which has been a basic part of antitrust law concepts" and "of the economic regime of the country."10

An only slightly less funereal comment came from the Court of Appeals for the Second Circuit in a case that had been argued before but was decided shortly after the Supreme Court's Parke, Davis decision. Holding that Parke, Davis entitled plaintiff to go to trial on his allegations of a conspiracy between a manufacturer and his dealers, Judge Moore noted that

the Colgate principles have not been completely destroyed. The Supreme Court has left a narrow channel through which a manufacturer may pass even though the facts would have to be of such Doric simplicity as to be somewhat rare in this day of complex business enterprise. ${ }^{11}$

We must, then, inquire whether in fact today, more than five years after the Parke, Davis case, Colgate is dead or almost worthless. Such inquiry should focus, first, on refusal to deal as a method to deter noncompliance with "suggested" resale prices. This is now more important than ever because the so-called "fair trade" laws, which authorize resale price maintenance contracts, have been held unconstitutional in many states at least in so far as they applied to nonsigners; ${ }^{12}$ hence,

\footnotetext{
${ }^{7}{ }_{32}$ U.S. at 37,38 .

8 Id. at 44 .

Id. at 49 .

${ }^{10}$ Id. at 57. See Levi, The Parke, Davis-Colgate Doctrine: The Ban on Resale Price Maintenance, Ig6o Sup. CT. Rev. 258.

${ }^{11}$ George W. Warner \& Co. v. Black \& Decker Mfg. Co., 277 F.2d 787, 790 (2d Cir. I960). Significantly, the defendant was "the world's largest manufacturer" in its line. See also Halpern, Individual Refusals to Deal: Customer Selection or Dealer Protection, 22 A.B.A. ANTITrust SEcrion 49, 5o (I963), suggesting that Colgate is "on the critically ailing list."

${ }_{12}$ According to 2 TRADE REg. REP. 16041 (Feb. 15, 1965), the acts have been held unconstitutional as applied to nonsigners in 22 states. Important manufacturers (like General Electric) have abandoned enforcement efforts. See, generally, ATr'y GeN. NAt'i CoMM. ANTITRUST REP. I49-54 (I955), recommending repeal of federal legislation permitting interstate enforcement of fair trade laws when resale is to be made in a state having a valid statute.
} 
refusal to sell to price-cutters may be the only method still available in such states to a manufacturer who wishes to influence the price policy of his dealers. ${ }^{13}$

However, the principle of Colgate was not limited to resale price maintenance, as its language quoted above ${ }^{14}$ indicates: It purported to establish a general freedom of customer selection, ${ }^{15}$ based on "independent discretion" and requiring only the absence of intention to create or maintain a monopoly. These more far-reaching aspects of Colgate also need exploration as to their current validity.

\section{I}

\section{Lawful Refusals to Seli to Those Who Do Not Observe Resale Pruces}

The most appropriate beginning of our story is the fate of a private treble damage action against Parke, Davis filed by Dart Drug Corporation, one of its retailers, after the Government had won its suit against Parke, Davis. It had been established in the Government civil litigation that the unlawful conspiracy between Parke, Davis and its distributors with regard to enforcement of resale price maintenance, as a result of which sales to Dart and others had been discontinued, had occurred in the summer of 1956 and ceased thereafter. ${ }^{18}$ From then on Dart was able to buy Parke, Davis products without any pressure as to resale prices. But in December I957 Dart was notified that Parke, Davis would no longer supply it directly, and subsequently Parke, Davis changed its distribution practices in such a way as to disable Dart from buying large package-sized Parke, Davis goods from wholesalers. Dart thereupon brought suit against Parke, Davis, pleading the Government judgment and alleging that the motive for the cut-off was the testimony of Dart's president in the Government's unsuccessful criminal prosecution against Parke, Davis.

Significantly, Dart did not claim that its cut-off by Parke, Davis in 1957 resulted from an agreement between Parke, Davis and others. Rather, Dart proceeded on the theory that it must be " "presumed that the conspiracy condemned by the Supreme Court ... was still in existence at the time Dart was cut off by Parke, Davis for the second time." "17

On that record the Court of Appeals for the District of Columbia Circuit affirmed

\footnotetext{
1s The agency method, i.e., selling through genuine common-law agents at prices determined by the manufacturer, sanctioned by United States v. General Elec. Co., 272 U.S. 476 (1926), seems to have been disapproved by Simpson v. Union Oil Co., 377 U.S. 13 (1964). See Lyons v. Westinghouse Elec. Corp., 235 F. Supp. 526 (S.D.N.Y. 1964); C.B.S. Business Equip. Corp. v. Underwood Corp., 240 F. Supp. 4I3 (S.D.N.Y. Ig64).

It See text accompanying note 2 stipra.

${ }^{10}$ Ace Beer Distrib., Inc. v. Kohn, Inc., 378 F.2d 283, 286 (6th Cir. 1963 ), cert. denied, 375 U.S. 982 (1964).

10 United States v. Parke, Davis \& Co., 365 U.S. 125 (I96r) (Government nevertheless entitled to judgment declaring the company had violated the law, and district court directed to retain the case on the docket for future action in the event of resumption of the conspiracy).

${ }^{17}$ Dart Drug Corp. v. Parke, Davis \& Co., 344 F.2d I73, I83, 194 (D.C. Cir. I965).
} 
a summary judgment in favor of Parke, Davis. ${ }^{18}$ The judgment against Parke, Davis obtained by the Government was prima facie evidence in favor of Dart that a conspiracy had been formed by Parke, Davis in 1956 and terminated in that same year $;^{10}$ hence, a conspiracy in 1957 had to be alleged and proven by Dart. In the absence of even an allegation of such a conspiracy, the court was compelled to assume that Dart's cut-off in I957 was unilateral and not collaborative; hence, a trial would have been useless. ${ }^{20}$

It would be entertaining to speculate how Dart and its counsel, after this defeat based on Colgate, now react to the view that the Supreme Court in Parke, Davis had "eviscerated"21 Colgate. Indeed the survival of Colgate was underscored by the additional holding that motivation of a cut-off by the desire to punish for price cutting "or anything else, however reprehensible" ${ }^{22}$ was not sufficient to establish illegality under section I of the Sherman Act. In this connection, the court referred with approval to the analogous recent decision of the Second Circuit in House of Materials, Inc. v. Simplicity Pattern Co., ${ }^{23}$ which held that a refusal to deal with a distributor in retaliation for the filing of a law suit by the latter seeking treble damages from the manufacturer for violation of the Robinson-Patman Act was not a restraint of trade but a unilateral act of "Doric simplicity" covered by Colgate.4 Dart would, of course, have been better off if it had been able to allege and prove that its cut-off by Parke, Davis was part of an attempt to monopolize. ${ }^{25}$

Some additional recent decisions suggest that the drawing of "demonstrable

${ }^{28}$ Dart Drug Corp. v. Parke, Davis \& Co., 344 F.2d 173 (D.C. Cir. 1965).

${ }^{10}$ Clayton Act $\$ 5(\mathrm{a}), 38$ Stat. 73I (IgI4), as amended, I5 U.S.C. $\$ 16(\mathrm{a})(1964)$.

so "To decide the issues before us we do not need to assay the meaning of Colgate in terms of demonstrable demarcations between unilateral and collaborative activities; our only essential frame of seference is the language of Section $r$. It continues, among the ebb and flow of cases trying to draw such lines, to make illegal only contracts, combinations, and conspiracies." Dart Drug Corp. v. Parke, Davis \& Co., 344 F.2d 173, 186 (D.C. Cir. 1965).

${ }^{21}$ United States v. Parke, Davis \& Co., 362 U.S. 29, 57 (1960) (dissenting opinion).

3344 F.2d at 186 . For the most recent dramatic example of reprehensible conduct held not to amount to a violation of the Sherman Act, see Eastern R.R. Presidents Conference v. Noerr Motor Freight, Inc., 365 U.S. 127, 145 (196r).

${ }_{23} 298$ F.2d 867 (2d Cir. 1962), reversing Husserl v. Simplicity Pattern Co., I91 F. Supp. 55 (S.D.N.Y. 196r). For critical comment on the lower court's decision, see Note, 62 CoIUM. L. Rev. 18r (I962), and on the upper court's reversal, Comment, 7I YALE L.J. I565 (I962).

24 298 F.2d at 870 . The critique of the decision in Comment, 7I YALE L.J. I565, I570 (I962), concedes that treble damage actions lie only for the redress of injuries "by reason of anything forbidden in the antitrust laws" [Clayton Act $\S 4,38$ Stat. 731 (I914), 15 U.S.C. $\S 1_{5}\left(196_{4}\right)$ ], but suggests that 2 private plaintiff suing a defendant against whom the Government had won a final judgment-as was the case here [see FTC v. Simplicity Pattern Co., 360 U.S. 55 (r959)]-should be able to obtain injunctive relief "for conduct which, although interfering with the enforcement of the antitrust laws, does not itself violate such laws." The argument would sweep aside the individual right of customer selection under circumstances that would make fruitful cooperation between manufacturer and dealer psychologically difficult, if not impossible. Moreover, the argument would not be applicable at all to private lawsuits not preceded by government litigation.

${ }^{95}$ In Bergen Drug Co. v. Parke, Davis \& Co., 307 F.2d 725, 727 (3d Cir. 1962), a wholesaler made such a claim in support of its action for treble damages and a permanent injunction and was held entitled to a preliminary injunction, since otherwise he could not have prosecuted the action. Colgate was held "inapposite." 
demarcations between unilateral and collaborative activities" ${ }^{20}$ sometimes results in finding the former and, therefore, leads to application of Colgate. Most significant is the recent decision of the Third Circuit in Klein v. American Luggage Works, Inc. $^{27}$ Defendant manufacturer listed its suggested retail prices in its catalogues and on price tags affixed to its merchandise. Its salesmen were instructed to advise new accounts other than department stores that full compliance with suggested retail prices was mandatory. Department stores were deemed not to need such warnings because the suggested prices reflected their normal mark-ups; defendant regularly sold to two department stores in the same city that at all times observed defendant's suggested prices.

Sales clerks of these two stores received from time to time complaints from potential customers that defendant's products were available elsewhere below preticketed prices. They passed on this information, which did not identify any specific merchant, to defendant's representative who serviced their accounts. Many months later two officers of defendant visited Klein's store in the course of a survey of retailers that was undertaken "to ascertain whether the most desirable outlets were utilized in marketing." They found Klein's display unattractive and discovered his discounting activities. One week later they sent Klein notice that defendant would no longer supply him. At a subsequent meeting with defendant's executives, Klein was advised that resumption of his account was conditional upon adherence to preticketed prices; Klein refused to accede.

The district court gave Klein a judgment for treble damages and an injunction on two grounds: It held that defendant had gone beyond a simple announcement of its policy to refuse dealings with price cutters and that there was a conspiracy between defendants and the two department stores. On the first point, the district court noted that dealers were "deluged with literature" emphasizing the importance of adherence to defendant's price policy and that defendant's solicitation practices made the acceptance of a new account "tantamount to an implied promise to comply with preticketed prices." ${ }^{\text {28 }}$ This destroyed the unilateral nature of defendant's conduct. The second ground rested on a finding of "tacit understandings" between defendant and the two department stores, and the latter's "volunteered assistance in the ascertainment of noncomplying dealers." ${ }^{29}$ The court of appeals found both grounds "clearly erroneous." In its view, the evidence established only that prospective retailers were advised of defendant's price maintenance policy, and there was no "shred of evidence" of conspiracy. There was, at most, "conscious parallelism" of action between the department stores, which was not the same as a conspiracy. ${ }^{30}$

\footnotetext{
${ }^{26}$ See note 20 supra.

${ }^{27} 323$ F.2d 787 (3d Cir. I963), reversing 206 F. Supp. 924 (D. Del. I962).

28206 F. Supp, at 943 .

29 Ibid.

${ }^{80} 323$ F.2d at 79r. The court relied on Theatre Enterprises, Inc. v. Paramount Film Distrib.
} 
This decision is an unambiguous reaffirmation of Colgate, in spite of the fact that the case was not even cited. The notion that any retailer who accepts goods for distribution with knowledge of the manufacturer's announcement as to observance of retail prices gives an implied promise to comply may be logical, but, as a general proposition, it is irreconcilable with Colgate, which allows advance announcements of the circumstances under which the manufacturer would refuse to deal. ${ }^{31}$ In addition, the absence of any enforcement methods on the part of defendant was decisive. There was no effort by defendant to enlist third persons in order to detect price cutters. The two department stores had received unsolicited complaints from the public that contained not even a hint as to the identity of the price cutter. They would have acted unreasonably and against their own interest had they concealed this from defendant's representative who supervised sales to them and visited them regularly. The inspection tour by defendant's officers was not caused by these revelations and represents a natural step for a manufacturer. Klein's price cutting activities were thus discovered by defendant alone, acting through its officers in the performance of their regular duties. This is a crucial point in establishing the unilateral character of defendant's refusal.

The Klein opinion shows that facts like those involved in Colgate still happen and that the result of Colgate seems reasonable when applied to such facts unless the Colgate rule were to be replaced by the novel proposition that unilateral action in aid of maintaining resale prices violates section I of the Sherman Act. ${ }^{22}$

One caveat should be added: The discussions between Klein and defendant's officers after Klein had received notice of his cut-off could be interpreted as an attempt by defendant to induce Klein to join in a resale price-fixing contract. This would not have altered the result in Klein, since such a contract was, presumably, sanctioned by Delaware law $^{33}$ and, therefore, exempt from federal antitrust prohibitions. ${ }^{34}$ In states with no fair-trade laws, such a contract would be invalid. The relevance of this is to be found in the recent statement of a district court that continuation of dealings should not be conditioned on the buyer's joining with the seller in an illegal contract and that such conduct was outside the "Colgate

Corp., 346 U.S. 537, 540-4I (1954), holding that the refusals to deal with plaintiff exhibitor by several defendant distributors were based on the independent decision of each.

${ }^{3}$ Perhaps manufacturers would be well advised not to "deluge" prospective dealers with literature in order to avoid the appearance of extreme pressure.

${ }^{32}$ In Dart Drug Corp. v. Parke, Davis \& Co., 344 F.2d I73, x86 (D.C. Cir. 1965), the court observed that such an argument had not been offered, nor does it seem to have been offered in any other case. As to the pertinent policy considerations, see infra, pp. 603-04.

${ }^{33}$ The Delaware Fair Trade Act, Dex. CODE ANN. tit. 6, $\$$ I90I-I907 (r953), including its nonsigner clause, was held constitutional in General Elec. Co. v. Klein, 34 Del. Ch. 49r, Io6 A.2d 206 (1954).

${ }^{84}$ Federal Trade Commission Act $\$ \$ 5(a)(2)-(5)$, as amended, 66 Stat. 63 I (1952), I5 U.S.C. $\$ \$ 45(a)(2)-(5)(1964)$, permits interstate enforcement of such contracts provided they are lawful in the state where the resale is to be made. Klein was a resident of Delaware. 
remnant."35 Manufacturers should consequently be cautious in offering conditions under which dealings previously terminated would be resumed, lest such negotiations, if successful, be interpreted as contracts rather than unilateral announcements.

On all fours with Klein is Graham v. Triangle Publications, Inc. ${ }^{38}$ Defendant, publisher of the Philadelphia Inquirer, raised the daily price of its paper from five cents to eight cents and announced that the paper would not be supplied to any dealer making a service charge. Plaintiff was cut off after defendant received numerous unsolicited complaints from subscribers protesting against plaintiff's service charge. The district court, citing Klein and Colgate, refused a preliminary injunction. ${ }^{37}$ Again, the refusal was an individual decision arrived at after discovery of the facts, and such discovery had occurred without any initiative on the seller's part and without enlistment by the seller of the help of other persons. ${ }^{88}$

Tobman v. Cottage Woodcraft Shop ${ }^{39}$ suggests that the Colgate rule is applicable even when the discovery of price cutting by the seller is not accidental but due to the seller's investigation. In that case, employees of defendant had ascertained the names of dealers who sold defendant's products below suggested prices, and the court held that this was unilateral since a corporation can act only through its agents and cannot conspire with itself. ${ }^{40}$ The additional fact distinguishing Tobman from Klein and Triangle is that in Tobman plaintiff's competitors told defendant's employee that plaintiff was cutting prices, whereupon the employee decided to visit

${ }^{25}$ A. H. Cayne Equip. Corp. v. Union Asbestos \& Rubber Co., 220 F. Supp. 784, 787 (S.D.N.Y. 1963) (defendant's demand that plaintiff purchase additional products as a condition of resuming sales to defendant held not to propose illegal tying because of absence of sufficient market power).

${ }^{38} 233$ F. Supp. 825 (E.D. Pa. 1964), aff'd per curiam, 344 F.2d 775 (3d Cir. 1965). See also Broussard v. Socony Mobil Oil Co., 226 F. Supp. 195 (W.D. La. 1964) (suit by cancelled dealer dismissed on authority of Colgatc; cancellation caused by refusal to follow suggested prices and bouncing checks), reversed, Trade Reg. ReP. (I965 Trade Cas.) I7I493, at 81203 (5th Cir., July 2, 1965), on the ground that more than mere refusal to sell was involved and therefore trial on plaintiff's allegations was required. Accord, Guidry v. Continental Oil Co., Trade Reg. Rep. (1965 Trade Cas.) \$71495, at 81210 (5th Cir., July 2, 1965), reversing order granting defendant's motion for summary judgment on ground that "Supplemental Bailment Agreement" authorizing defendant to terminate plaintiff's whole service station business was not sanctioned by Colgate. But see Alexander v. Texas Co., I 49 F. Supp. 37 (W.D. La. I957), I65 F. Supp. 53 (W.D. La. 1958); G. D. Searle \& Co. v. Institutional Drug Distrib., Inc., I5I F. Supp. 715, 724, 725 (S.D. Cal. 1957) In the last case cited, the defense of unclean hands to an action for trademark infringement was rejected on the authority of Colgate. Defendant was permitted to make bids for Searle products at list prices and was to collect the price from hospitals and turn $90 \%$ of the amount collected over to Searle. The privilege was withdrawn by Searle when it learned that defendant had made bids below list price. There was no explanation of how Searle had discovered this, and the court stressed the existence of ample competition for all Searle products.

${ }^{37}$ The defendant in the Triangle case had obtained written declarations of compliance from seven dealers. The court assumed, at least for the purpose of a hearing on a preliminary injunction, that these contracts were valid under the Pennsylvania Fair Trade Act, 73 PA. Stat. ANN. $\$ \$ 7-1$ I (1960).

${ }^{28}$ Compare Ayer, Inc. v. FTC, 15 F.2d 274, 276 (2d Cir. 1926), cert. denied, 273 U.S. 759 (1927), for similar criteria of unilateral action.

${ }^{30}$ I94 F. Supp. 83 (S.D. Cal. I96r).

${ }^{10} \mathrm{r} 94$ F. Supp. at 87 , citing Nelson Radio \& Supply Co. v. Motorola, Inc., 200 F.2d 91r, 914 (5th Cir. I952), cert. denied, 345 U.S. 925 (I953). Cf. Kiefer-Stewart Co. v. Seagram \& Sons, 340 U.S. 211,215 (I95I) (two subsidiaries of the same parent corporation may conspire with each other, "especially" where they "hold themselves out as competitors"). See ATr'y GeN. Nat'z Coms. ANTITrust REP. 30-36 (I955). 
plaintiff in order to verify the charge. Since, however, the plaintiff's competitors had volunteered this information and plaintiff had been cut off only after defendant had made an independent investigation, it would seem to be impossible to find a conspiracy with defendant. The result would have been different if defendant's agents had discussed the matter with plaintiff's competitors and assured them that defendant would select only jobbers over whose practices it could "exercise some control"; ${ }^{41}$ such evidence would have supported a finding of a conspiracy. ${ }^{42}$ Perhaps these factual distinctions appear unduly refined or artificial. Yet, we are operating under a statute that applies only to combinations or conspiracies, "one of the most difficult areas of today's law." 43 In other words, the troublesome distinction between unilateral and conspiratorial acts was not invented by Colgate but by Congress when it framed the language of section I of the Sherman Act, and that distinction pervades the entire field of antitrust. Indeed, it reaches into the common law of torts, which holds that what is lawful if done by an individual may become unlawful if done by two or more persons acting in concert. ${ }^{44}$

II

\section{Termination of Distributorship for Reasons Not Involving Resale Prices}

Since, in the absence of an attempt to achieve or maintain a monopoly, Colgate guarantees the right of customer selection, a manufacturer must be free, in so far as the antitrust laws are concerned, ${ }^{45}$ to replace an existing distributor with a new one regardless of the hardship for the former and even in the absence of any plausible justification. The courts have consistently so held. ${ }^{48}$

${ }^{11}$ Girardi v. Gates Rubber Co. Sales Division, Inc., 325 F.2d 196, 202 (9th Cir. 1963), reversing a judgment dismissing a treble damage suit.

${ }^{43}$ Id. at 199 (elimination of one single jobber at the instance of a competing jobber sufficient to find a conspiracy).

${ }^{3}$ Flintkote Co. v. Lysfjord, 246 F.2d 368, 378 (9th Cir.), cert. denied, 355 U.S. 835 (I957).

i See Restatement, Torts $\$ 765$, comment a (1939).

${ }^{45}$ The statement in the text refers to the antitrust laws only. Common law remedies are not within the scope of this paper.

10 Ace Beer Distrib., Inc. v. Kohn, Inc., 318 F.2d 283,287 (6th Cir.), cert. denied, 375 U.S. 922 (I963) ("The substitution of one distributor for another in a competitive market . . . does not eliminate or materially diminish the existing competition of distributors of other beers, is not an unusual business procedure, and ... not an unreasonable restraint of trade"); Parmelee Transp. Co. v. Keeshin, 292 F.2d 794 (7th Cir.), cert. denied, 368 U.S. 944 (196I) (award by railroads of exclusive contract to transfer passengers between Chicago terminals to new organization rather than plaintiff, which had rendered satisfactory services, did not violate antitrust laws even though award may have been facilitated by official misconduct); Naifeh v. Ronson Art Metal Works, 2r8 F.2d 202 (Ioth Cir. 1954); Schwing Motor Co. v. Hudson Sales Corp., 138 F. Supp. 899, 906 (D. Md.), aff'd per curiam, 239 F.2d I76 (4th Cir. 1956), cert. denied, 355 U.S. 823 (1957) (allegation that recently established dealer induced defendant to replace plaintiff held insufficient to show conspiracy; ". - . a manufacturer would not decide to reduce the number of its dealers in a particular city .... without discussing the matter with the dealers or dealer whom it wished to retain"). Accord, Packard Motor Car Co. v. Webster Motor Car Co., 243 F.2d 418 (D.C. Cir.), cert. denied, 355 U.S. 822 (I957). See also Hohensee v. Akron Beacon Publishers Journal, 174 F. Supp. 450 (N.D. Ohio 1959), aff'd per curiam, 277 F.2d 359 (6th Cir.), cert. denied, 364 U.S. $91_{4}$ (I960). For special problems under the Auto- 
The ousted dealer may contend that the manufacturer's contract with the new distributor is in restraint of trade, particularly when the manufacturer substitutes for previously existing multiple dealerships an exclusive dealership, which may or may not be limited to a particular territory. This argument has been rejected when applied to manufacturers who do not enjoy monopoly positions ${ }^{47}$ since the goods involved are subject to competition by other products and the purpose of the arrangement is to secure for the manufacturer a prospectively increasing outlet and for the distributor a reliable source of supply. ${ }^{48}$

Complications arise, however, when the individual freedom of refusing to deal may appear to collide with the policy of section 3 of the Clayton Act, ${ }^{40}$ which prohibits leases or sales, or contracts for sale, of goods on the condition that the lessee or purchaser shall not deal in goods of a competitor of the lessor or seller if the effect of such transaction "may be to substantially lessen competition or tend to create a monopoly in any line of commerce." This includes not only a promise of "exclusive dealing" by the distributor ${ }^{50}$ but also tying arrangements, which, by definition, involve refusals to sell the tying product without simultaneous sale of the tied product. Section 3, of course, applies only to leases, sales, or contracts; the problem before us is presented by refusals to deal which occur because the distributor handles competitive goods or because he does not buy tied articles. Is such a refusal an invitation to distributors to drop competing lines or to absorb tied goods which, if accepted, becomes either a contract forbidden by section 3 of the Clayton

mobile Dealer Franchise Act of 1956, 70 Stat. 1125 (1956), 15 U.S.C. \$\$ 1221-25 (1964), see Kessler, Automobile Dealer Franchises: Vertical Integration by Contract, 66 YALE L.J. I135 (1957). Lawsuits by dealers who claimed not to have been treated in "good faith," as defined in $\$ 1(c)$ of the Act, have been unsuccessful in the appellate courts on the ground that the manufacturer, in terminating relations, did not use coercion or intimidation but was motivated by reasonable business judgment as to dealer's performance and qualifications. Milos v. Ford Motor Co., 317 F.2d 712 (3d Cir.), cert. denied, 375 U.S. 896 (1963); Globe Motors, Inc. v. Studebaker-Packard Corp., 328 F.2d 645 (3d Cir. 1964); Abbott-Stansell Motor Co. v. Chrysler Motors Corp., 333 F.2d 322 (5th Cir. 1964); Woodard v. General Motors Corp., 298 F.2d 121 (5th Cir.), cert. denied, 369 U.S. 887 (1962); Garvin v. American Motors Sales Corp., 318 F.2d 518 (3d Cir. 1963); Kotula v. Ford Motor Co., 338 F.2d 732 (8th Cir. I964), cert. denied, 380 U.S. 979 (1965); Pierce Ford Sales, Inc. v. Ford Motor Co., 299 F.2d 425 (2d Cir.), cert. denied, 371 U.S. 829 (1962).

${ }^{47}$ Schwing Motor Co. v. Hudson Sales Corp., supra note 46 ; Packard Motor Car Co. v. Webster Motor Car Co., supra note 46; Bascom Launder Corp. v. Telecoin Corp., 204 F.2d 33I (2d Cir.), cert. denied, 345 U.S. 994 (1953) (judgment holding contract between Bendix and Telecoin giving latter exclusive franchise of former's products illegal per se reversed and remanded for jury trial on issues of Bendix's monopoly and reasonable business purposes); Fargo Glass \& Paint Co. v. Globe American Corp., 201 F.2d 534 (7th Cir.), cert. denied, 345 U.S. 942 (1953).

"I In United States v. Bausch \& Lomb Optical Co., 45 F. Supp. 387, 398-400 (S.D.N.Y. 1942), such an arrangement involving a promise by a manufacturer not to sell to other distributors was sustained, although agreements by the distributor relating to subsequent distribution were held violative of the Sherman Act. The judgment in favor of the manufacturer was affirmed by an equally divided Supreme Court. 321 U.S. 707, 709, 719 (1944). The division of the Court may have been over the question whether the two distribution systems could be regarded as separable. See AtT'y GeN. NAt'l Comm. ANTITRUST ReP. 27-29 (1955).

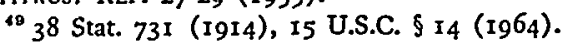

60 As distinguished from the manufacturer's promise to sell to an exclusive distributor, discussed in the preceding paragraph. 
Act or a combination or conspiracy in restraint of trade $?^{51}$ Or is it a unilateral act sanctioned by Colgate?

The cases have generally adopted the latter approach. Regularly cited to this day is the 1952 case of Nelson Radio Supply Co.v. Motorola, Inc. ${ }^{52}$ After plaintiff had sold defendant Motorola's products for several years, defendant, whose sales allegedly amounted to more than fifty per cent of the relevant market, submitted a new agreement to plaintiff. The negotiations were fruitless because defendant resisted plaintiff's demand that it be allowed to sell Motorola communications equipment together with equipment acquired from other manufacturers. Defendant refused to enter into a new contract unless plaintiff would forego its demands. The court referred to defendant's exclusive wholesale distributorship contracts in other areas as presumably coming under the ban of section 3 of the Clayton Act ${ }^{53}$ but affirmed a dismissal of the complaint for treble damages on the ground that section 3 covered only contracts, not refusals to contract, and that "a manufacturer has the unquestioned right to refuse to deal with anyone for reasons sufficient to himself," citing Colgate..$^{54}$ If plaintiff had signed an exclusive dealing contract in accordance with Motorola's wishes, it might have succeeded in obtaining damages, ${ }^{55}$ particularly in view of Motorola's alleged leading market position, which the court ignored.

Here again we should note the statement by Judge MacMahon of the Southern District of New York, in A. H. Cayne Equip. Corp. v. Union Asbestos \& Rubber Co.," that "refusals to continue to deal unless the buyer join with the seller in a contract violative of the antitrust laws are clearly illegal." Defendant in that case had refused to continue selling to plaintiff unless the latter agreed to purchase additional products not previously handled by him. Plaintiff's complaint was dismissed on the ground that the tying arrangement proposed by defendant was not illegal because defendant lacked the economic power to induce his customers to take the tied product along with the tying item and the amount of commerce involved was not substantial. ${ }^{57}$ But if the proposal had been evaluated differently, as were Motorola's exclusive dealing contracts, defendant's refusal to deal would have been held unlawful.

\footnotetext{
${ }^{01}$ The latter approach is suggested in Note, 64 YALE L.J. 581, 586 (I955), pointing to Interstate Circuit, Inc. v. United States, 306 U.S. 208 (1939) (price-fixing conspiracy implied from circumstantial evidence), as an analogy.

${ }^{52} 200$ F.2d 911 (5th Cir. I952), cert. denied, 345 U.S. 925 (1953), followed in Meyberg Co. v. Eurcka Williams Corp., 215 F.2d Ioo (9th Cir.), cert. denied, 348 U.S. 875 (I954).

${ }^{68} 200$ F.2d at 915. In Alles Corp. v. Senco Prods., Inc., 329 F.2d 567 (6th Cir. I964), a market share of $50 \%$ was held sufficient to hold an implied exclusive dealing contract invalid under $\$ 3$ of the Clayton Act and $\$ 2$ of the Sherman Act.

54200 F.2d at 915.

to One writer so suggests. Note, 64 YALE L.J. $58 x, 584$ (1955). The comment is well taken, provided plaintiff, who would then be a party to an illegal contract, were not in pari delicto with defendant.

to 220 F. Supp. 784,787 (S.D.N.Y. 1963), referred to in note 35 supra and accompanying text.

${ }^{77}$ See generally Turner, The Validity of Tying Arrangements Under the Antitrust Laws, 72 HARv. L. Rev. 50 (1958). See also United States v. Loew's, Inc., 37 I.S. 38 (I962), holding illegal under $\S \mathrm{x}$ of the Sherman Act block booking of copyrighted motion pictures for television exhibition.
} 
The fact that Judge MacMahon's doctrine was formulated in a tying case may be significant because refusal to sell except under the seller's condition (that the tied item also be bought) is the very essence of tying; therefore, the Supreme Court has sustained injunctions forbidding such refusals where sellers had found buyers willing to accept such agreements. ${ }^{58}$ Yet, there would seem to be no reason to deny general applicability to Judge MacMahon's proposed qualification of Colgate. The right of refusal to deal is incompatible with the policy of the antitrust laws not only when it is employed to achieve or maintain a monopoly ${ }^{60}$ but also when it is used as a means to induce contracts in restraint of trade. Such use is a misuse, which should bar the exercise of the right until the misuse is discontinued. ${ }^{60}$ The party alleging misuse would have the burden of proving that there was an offer of a contract in violation of the antitrust laws.

A second noteworthy feature of the Motorola opinion is the absence of any comment on Motorola's business motives. Some subsequent decisions that have cited Motorola are in marked contrast. For instance, in Hudson Sales Corp. v. Waldrip, ${ }^{\text {61 }}$ the Court of Appeals for the Fifth Circuit, reversing a judgment for an ousted dealer who had also sold Philco and Willys products in addition to the defendant's observed

that plaintiff was too spread out, his efforts too dispersed, to give Hudson the effective representation as master dealer in his territory to which Hudson was entitled; that it did this under its policy . . . to select master dealers who would best serve Hudson's interest; and that, having first endeavored to induce plaintiff to produce more worthwhile results, and having found that plaintiff was unable or unwilling to give it the satisfactory service it was entitled to, defendant . . . simply declined to renew [plaintiff's contract]. ${ }^{62}$

The court added that even if it were to be assumed that the contract between the parties required plaintiff not to deal in the products of other manufacturers, this could not have had the probable anticompetitive effect necessary to make out a violation of section 3 of the Clayton Act. ${ }^{63}$ It follows that a refusal to renew plaintiff's contract unless he agreed to exclusive dealing would, under Judge MacMahon's doctrine, not have altered the decision in favor of defendant.

\footnotetext{
${ }^{68}$ United States v. Loew's, Inc., 37I U.S. $38,55,56$ (1962); United States v. Paramount Pictures, Inc., 334 U.S. I3I, 159 (I948).

${ }^{60}$ Lorain Journal Co. v. United States, 342 U.S. I43 (195I); Eastman Kodat: Co. v. Southern Photo Materials Co., 273 U.S. 359 (I927).

${ }^{80} \mathrm{By}$ analogy to the familar doctrine of patent misuse. ATr'y GeN. Nat't Comm. ANTrtrust Rep. 250-5I (I955). Cf. Preformed Line Prods. Co. v. Fanner Mfg. Co., 225 F. Supp. 762, 789, 793 (N.D. Ohio I962), aff'd 328 F.2d 265, 276, 277 (6th Cir. 1964) (defense of misuse to patent infringement suit sustained; sale of plaintiff's patented products was refused unless defendant would buy related unpatented items).

612 II F.2d 268 (5th Cir. 1954).

"Id at 273. Accord, United States v. J. I. Case Co., ror F. Supp. 856, 864 (D. Minn. 195x) ("The contracts as to a substantial number of such dealers were not renewed due to the nonprogressiveness of the dealer ....").

${ }_{68} 211$ F.2d at 273.
} 
Similarly, in McElhenny Co. v. Western Auto Supply Co., ${ }^{64}$ five discontinued retailers were unsuccessful in their efforts to obtain treble damages for violation of section 3 of the Clayton Act and section 2 of the Sherman Act. Their contracts permitted cancellation at will on notice. Plaintiffs alleged that they had refused to drop sales of "outside" products, particularly TV sets that sold better than those of defendant. The court of appeals, affirming a judgment dismissing the complaint, noted that defendant "wanted its dealers to advance sales of its merchandise, and threatened with cancellation and actually cancelled dealers who patronized its competitors to an extent which it felt jeopardized the value to it of the franchises issued to" such dealers. ${ }^{65}$ There was thus no agreement within the meaning of section 3 of the Clayton Act but only a lawful refusal to sell; there was also no charge that defendant's goods were not available in other stores nor any averment of monopoly in any defined market. In short, these cases suggest that a non-monopolistic manufacturer, not conspiring with anyone, "has the right to select dealers who will devote their time and energies to selling his products," and that he is not compelled to retain dealers "with divided loyalties adverse to his interests."

The notion that a manufacturer should not be forced to continue entrusting the marketing of his products to such a dealer reflects sound business considerations. It appeared to be particularly plausible in Deltown Foods, Inc. v. Tropicana Prods, Inc. ${ }^{67}$ Plaintiffs, milk processors and distributors, handled defendant's orange juice, which accounted for three per cent of their annual business. Upon learning that plaintiffs had begun selling their own orange juice under their own private brand, defendant discontinued selling to plaintiffs on the ground that it would be business suicide to have plaintiffs treat defendant's product as second best. The denial of a preliminary injunction was justified not only on the usual grounds that a refusal to deal does not fall within the purview of section 3 of the Clayton Act but also on the further ground that section 3 could not be applied to a situation where the buyer was a competitor of the seller. ${ }^{68}$

\footnotetext{
e4 269 F.2d 332 (4th Cir. 1959).

${ }^{05}$ Id. at 338. Accord, Timken Roller Bearing Co. v. FTC, 299 F.2d 840 (6th Cir. I962). In this this case, salesmen recommended new accounts to the home office on the ground they would be "loyal," which meant that they would primarily devote themselves to the sale of Timken products. Those cancelled had bought no, or almost no, Timken bearings for a long period. The Commission's case rested on only one witness; 37 witnesses said they were free to deal in competing products and "had actually done so to some extent."

${ }^{B 0}$ Walker Distrib. Co. v. Lucky Lager Brewing Co., 323 F.2d $x$, Io (9th Cir. I963). In this case, the court affirmed a judgment dismissing a counterclaim to an action for the purchase price of beer; the buyer had alleged that the seller terminated his distributorship because he, the buyer, insisted on also selling competing brands. Again, the court stressed that rival beer was not prevented from gaining a foothold in the market and that refusal is not the same as a contract. To the same effect see Alpha Distrib. Co. v. Jack Daniels Distillery, 207 F. Supp. I36, I3 $_{3}$ (N. D. Cal. I96r), aff'd per curiam, 304 F.2d 45r (9th Cir. 1962); Campbell Distrib. Co. v. J. Schlitz Brewing Co., 208 F. Supp. 523 (D. Md. x962) (in spite of Schlitz's relatively large size, no "dangerous probability" was found that monopoly could be achieved by refusal to sell).

${ }^{17} 219$ F. Supp. 887 (S.D.N.Y. 1963).

${ }^{08} \mathrm{Id}$. at $8 \mathrm{gr}$. The opposite result was reached in McKesson \& Robbins, Inc. v. Charles Pfizer \& Co.,
} 
A similar realism is reflected in two recent appellate court decisions involving alleged tying arrangements. In Dehydrating Process Co. v. A. O. Smith Corp., ${ }^{00}$ defendant was the manufacturer of a patented glass-lined silo and a patented unloader. The latter is a sweep-arm, installed inside at the bottom of the silo. After having for seven years sold the unloader separately from the silo, defendant announced that it would refuse selling unloaders unless they were to be installed in silos of its own manufacture. Plaintiff claimed treble damages, but the First Circuit accepted the defense that fifty per cent of all customers who bought defendant's unloaders for use in silos made by others had complained about unsatisfactory results in spite of defendant's educational efforts as to proper use of this equipment; this was sufficient "business justification" as a matrer of law.70

On the same ground rests Crawford Transp. Co. v. Chrysler Corp. ${ }^{71}$ Chrysler announced that it would reduce from eighty to sixteen the number of motor carriers whose services it planned to retain, the selection to be made on the basis of past performance, financial stability, and adequacy of certificates. Dealers would no longer be free to select carriers for transportation of Chrysler cars from the plant; the retained carriers would be expected to solicit all Chrysler business. Chrysler expressed the hope that they would not increase their rates, would use Chryslerbuilt trucks, and would not enter into interchange agreements with nonretained truckers without prior approval by Chrysler. The plan, which was discussed with the retained carriers, was expected to save millions in annual shipping costs. The Sixth Circuit affirmed a judgment for Chrysler holding that this was not a tying arrangement condemned by section I of the Sherman Act; in the first place, it did not fit the definition of tying, since the seller (Chrysler) did not expect to participate in the profits flowing from the sale of the tied item, i.e., the transportation service. ${ }^{72}$ Rather "Chrysler's decision to reduce the number of motor carriers to

235 F. Supp. 743 (E.D. Pa. I964), in which defendant's justification for cutting off sales after plaintiff had become a competitor was rejected because refusal to deal furthered an alleged conspiracy to fix and maintain price on defendant's patented drug, a major antibiotic which was obtainablc only by physician's prescription. The court distinguished terminations of wholesalers "for sound business reasons." Id. at 747 .

${ }^{69} 292$ F.2d 653 (Ist Cir.), cert. denied, 368 U.S. 93I (r96I).

${ }^{70}$ It may be said that the silo and unloader could not be treated as separate products. See United States v. Jerrold Electronies Corp., 187 F. Supp. 545, 559 (E.D. Pa. 1960), aff'd per curiam, 365 U.S. $567(196 \mathrm{r})$.

${ }_{71} 338$ F.2d 934 (6th Cir. I964), cert. denied, 380 U.S. 954 (r965).

${ }^{72} 338$ F.2d at 938 . The court distinguished United States v. General Motors Corp., I21 F.2d 376 (7th Cir. I94I), and Osborn v. Sinclair Ref. Co., 286 F.2d 832 (4th Cir.), cert. denied, 366 U.S. 963 (I96r), on that ground. On the other hand, Miller Motors, Inc. v. Ford Motor Co., 252 F.2d $44 \mathrm{I}$ (4th Cir. 1958), was comparable to the Chrysler case. There a damage action by a former dealer was dismissed; Ford's insistence that plaintiff belong and contribute to a dealers' advertising fund, which was a cooperative venture beneficial to dealers, was held reasonable. Accord, Nelligan v. Ford Motor Co., 262 F.2d 556 (4th Cir. 1959). These cases do not appear to conflict with the recent decision in Atlantic Ref. Co. v. FTC, 381 U.S. 357 (1965), striking down as an unfair trade practice an agrcement between Atlantic and Goodyear under which Atlantic forced its service stations to buy Gondyear products, on sales of which Atlantic received commissions. Hence, the anticompetitive effect of the 
whom it tendered traffic was a unilateral one made by it for the sole purpose of obtaining a more efficient and economical distribution of its products ..."73 and thereby to increase its competitive strength in an oligopolistic industry. ${ }^{74}$

\section{III}

\section{General Significance of the Demarcation Between Unilateral and Concerted Action}

The preceding discussion of the recent cases shows that Colgate is still very much alive, although reliance on Colgate as a means to induce resale price maintenance appears to be difficult and successful only in relatively few instances, while refusals to deal motivated by other purposes are more frequently approved. In all cases such approval depends, of course, on whether the refuser can convince the court that his action was unilateral.

As already indicated, the distinction between unilateral and collaborative or conspiratorial action is fundamental in the American antitrust system and could not be done away with without altering the Sherman Act. Indeed, it is hardly necessary to call attention to the fact that at least two independent business entities ${ }^{75}$ are required for violation of section $I$, while one alone may be liable under section 2 . This statutory scheme reflects a philosophy that exalts the liberty and initiative of the individual enterprise and looks with suspicion on collective action. The latter is inherently dangerous because it represents aggregations of power that are likely to be used in a manner detrimental to the public interest. This is the ultimate reason for the necessity of drawing "demonstrable demarcations"78 between individual and group conduct.

Such demarcations are particularly important with respect to refusals to deal because collective boycotts are presumptively illegal per $s e ;^{77}$ at least, they have been approved as reasonable and not inimical to competition only on very rare

agreement was its principal purpose, and evidence of "economic justification" was properly rejected. $3^{81}$ U.S. at 37I. In the Chrysler case, there were no formal agreements with the dealers, and the economic justification of Chrysler's policy seemed paramount since Chrysler did not participate in the increased profits of the retained carriers.

${ }^{12} 33^{8}$ F.2d at 940 .

IId. at 939. The court, citing Colgate, referred to the public interest in allowing Chrysler to increase its competitive strength vis-à-vis Ford and General Motors. Note that Chrysler's discussions with the retained carriers did not prevent the court from characterizing Chrysler's action as unilateral, for the same reasons as set forth in Schwing Motor Co. v. Hudson Sales Corp., I38 F. Supp. 899, 906 (D. Md. I956).

"75 For purposes of our problem, the doctrine of intraenterprise conspiracy has been rejected (see note 40 supra and accompanying text) and with good reason. Since a firm can act only through its agents, individual refusals to deal would otherwise have to be limited to individual natural persons doing business alone without employees.

Tee note 20 supra and text accompanying note 26 supra.

${ }^{77}$ See Barber, Refusals to Deal Under the Federal Antitrust Laws, 103 U. PA. L. REv. 847, 872-79 (1955), for a discussion of the leading cases. See also Restatement, Torts $\$ 765$ and comments (1939). 
occasions. $^{78}$ On the other hand, identical refusals by every member of a group may be construed as individual and unilateral action by each member, although each member knew that every other member would act in the same way. The classic illustration is Theatre Enterprises, Inc. v. Paramount Film Distrib. Corp., ${ }^{70}$ where motion picture producers and distributors refused plaintiff's request for an exclusive first-run license. Plaintiff's contention that this was a collective boycott was rejected on the ground that parallel business behavior does not conclusively establish agreement or conspiracy; since plaintiff owned a suburban theatre, with a drawing area of less than one-tenth that of the theatres in the downtown section, granting of plaintiff's request would have been so obviously an unwise business proposition that each defendant independently could not but reach the same decision. ${ }^{80}$ Under such circumstances, courts are inclined to find a series of unilateral actions rather than a conspiracy, even when the former may have the same detrimental effect on competition as the latter. This reveals a basic weakness in the structure of the Sherman Act. ${ }^{81}$

\section{IV}

\section{Conclusions}

How should we evaluate the practical application of the right of unilateral refusal? As mentioned above, use of this right in furtherance of resale price maintenance is still possible, provided the detection of price cutting is accidental or

\footnotetext{
${ }^{78}$ Ruddy Brook Clothes, Inc. v. British \& Foreign Marine Ins. Co., I95 F.2d 86, 89 (7th Cir.). cert. denied, 344 U.S. 816 (1952) ("If plaintiff's theory is accepted, it . . . would inevitably lead to the result that concerted refusal to sell fire insurance to a known fire-bug or concerted refusal to sell fire arms to a known or suspected bank robber would constitute a violation of the Sherman Act"); United States v. National Football League, I16 F. Supp. 319 (E.D. Pa. I953) (contractual restriction preventing telecasts of outside games into home territories of other teams on days when other tcams were playing at home sustained as reasonable protection of gate receipts). See also Radiant Burners, Inc. v. Peoples Gas Light \& Coke Co., 364 U.S. 656, 658 (1961), for a dictum that "objective standards" for withholding a seal of approval from unsafe gas burners by trade association may be justifiable.

${ }^{70} 346$ U.S. 537 (1964).

${ }^{80}$ Accord, Delaware Valley Marine Supply Co. v. American Tobacco Co., 297 F.2d 199 (3d Cir. I961), cert. denied, 369 U.S. 839 ( 1962 ) (major tobacco companies refused to give plaintiff listing enabling it to purchase cigarettes tax-free for resale to ships in port of Philadelphia; motion for dirceted verdict in favor of defendant affirmed on ground that uniform action of defendants did not show conspiracy but plausible business reasons justifying inference of individual decisions by each). An analogous example involving price-fixing is to be found in Pevely Dairy Co. v. United States, I78 F.2d 363 (8th Cir. 1949), cert. denied, 339 U.S. 942 (1950) (conviction for price-fixing reversed since alleged conspirators paid their suppliers identical prices set by federal regulation, their labor costs were identical due to contracts with the same union, and their products were standardized by local health ordinances).

${ }^{81}$ See generally Rahl, Conspiracy and the Antitrust Laws, 44 ILx. L. Rev. 743 (r950); Conant, Consciously Parallel Action in Restraint of Trade, 38 MinN. L. REv. 797 (1954); ATt'y GeN. NaT'L COMM. ANTITRUst REP. 39 (1955) ("Can the conduct, no matter how uniform, be adequately explained by independent business justifications?"). Cf. Schwartz, New Approaches to the Control of Oligopoly, rog U. PA. L. Rev. 3I, 40 et seq. (I960), referring to the closely related doctrine of "price leadership," where the damaging effect on competition is the same whether price uniformity occurs as a result of imitation or agreement. See Lodis B. Schwartz, Free ENTERPRise aNd Economic Organization 349-6r (2d ed. 1959).
} 
unsolicited and solely the result of the manufacturer's own effort. Although several recent cases have found these requirements satisfied, ${ }^{82}$ this cannot too easily be done. As a matter of public policy, this result is satisfactory because the manufacturer's interest in influencing resale prices does not deserve more extensive recognition and protection. The mythology of the "fair trade" laws, which permit control of such prices, has been exposed for a long time; ${ }^{83}$ in a truly competitive system, the manufacturer should be content to rely on the quality of his products and the efficiency of his distributors. Hence, it may be desirable to forbid even unilateral attempts at "suggesting" resale prices, but such a rule could not be derived from section I of the Sherman Act. ${ }^{84}$

The cases sanctioning refusals to deal for reasons not connected with resale price maintenance concern less sensitive areas where it is much easier to find business justification for the refusal. The crucial question should always be this: What result is to be brought about by the refusal? It is settled that if it is the acquisition or retention of monopoly, the refusal is actionable. It is also suggested by what we have called Judge MacMahon's doctrine that if the refusal is intended as a means to coerce the other side into a contract violative of the antitrust laws, it should not be permitted. But not every contract which restrains the freedom of a trader is illegal; particularly, the Supreme Court has recognized in White Motor Co. $v$. United States, ${ }^{85}$ and at least two circuits have since held, that restrictions on the freedom of distributors as to territories or types of customers may be reasonable when necessary to assure to a manufacturer an efficient distribution system without which he could not give battle to his competitors. ${ }^{86}$

That very same philosophy is reflected in the refusal-to-deal cases discussed above. They protect the right of manufacturers to select only those dealers who will make real efforts to push their products and to discard those who do not. That is the real meaning of the technical distinction between a refusal to deal with a distributor on

\footnotetext{
${ }^{82}$ In addition to those cases previousiy discussed, see Best Advertising Corp. v. Illinois Bell Tel. Co., 339 F.2d 1009, 1012 (7th Cir. 1965) (dissenting opinion of Judge Swygert). Defendant Donnelley, authorized to solicit advertisements for yellow pages of telephone directory, refused to deal with plaintiff's advertising agency. A treble damage action under $\$ \$ I$ and 2 of the Sherman Act was dismissed. The dissent would have-correctly, I believe-reversed on the ground of monopoly effect of telephone advertising. See also Azzee Supply Corp. v. Ruberoid Co., 222 F. Supp. 237 (D. Conn. 1963), where there was a compliant of conspiracy by an ousted Ruberoid dealer, who alleged that two of plaintiff's competitors, but not Ruberoid, were members of a conspiracy; no group boycott was found, since the refusal to deal was on the part of Ruberoid alone. (The case shows how not to plead but hardly anything else.) And, finally, see Julius M. Ames Co. v. Bostitch, Inc., 240 F. Supp. 521, 526-28 (S.D.N.Y. 1965) (question of unilateralism requires trial).

${ }^{83}$ See note 12 supra, and Fulda, Resale Price Maintenance, 21 U. Crr. L. Rev. I75-211 (I954).

86 Perhaps the Federal Trade Commission might try some day to establish such a rule under $\$ 5$ of the Federal Trade Commission Act, $3_{8}$ Stat. 719 (I9r4), as amended, I5 U.S.C. 545 (1964).

${ }^{85} 372$ U.S. 253 (1963).

${ }^{80}$ Such restrictions have been sustained in Sandura Co. v. FTC, 339 F.2d 847 (6th Cir. 1964), and Snap-On Tools Corp. v. FTC, 32 I F.2d 825 (7th Cir. I963), on the ground that they were necessary to insure the competitive survival of the manufacturers using such arrangements. See also United States v. Arnold, Schwinn \& Co., 237 F. Supp. 323, 343 (N.D. Ill. 1965) (no Sherman Act violation "in allocating specific territories to distributors for prime responsibility").
} 
the one hand and a contract obligating him to refrain from dealing in competing products on the other; such contracts are, of course, illegal only when they may have the requisite anticompetitive effect in the relevant market. ${ }^{87}$ A manufacturer should, therefore, be free to refuse renewal of franchises when he cannot count on identity of interest with his dealers. Under such circumstances, the competitive order is not endangered but likely to be enhanced by permitting the manufacturer to insist that his dealers consider his products as their primary responsibility. The dealers will do this anyway if the product is attractive enough.

All told, the recent cases surveyed here seem to achieve fairly workable guidelines in protecting the freedom of individual traders from unnecessary restrictions and in recognizing conduct likely to increase competitive efficiency. ${ }^{88}$ And, curiously enough, it is all done with the aid of that old case that had to be rescued from the undertaker.

\footnotetext{
${ }^{87}$ Tampa Elec. Co. v. Nashville Coal Co., 365 U.S. 320 (I96r). On the other hand, price-fixing contracts, including resale price maintenance contracts, are illegal per se. (1965).

${ }^{8}$ See Blake \& Jones, Toward a Three-Dimensional Antitrust Policy, 65 Couum. L. Rev. 422, 436
} 